Gabriela Rękal, Anna Korzeniowskal, Piotr Machowiec ${ }^{l}$,

Marcela Maksymowicz', Halina Piecewicz-Szczęsna ${ }^{2}$

\title{
IMPACT OF LEVEL OF VITAMIN D IN THE BODY ON THE SEVERITY OF COVID-19 - REVIEW OF THE LITERATURE
}

\section{WPŁYW POZIOMU WITAMINY D W ORGANIZMIE NA STOPIEŃ CIĘŻKOŚCI PRZEBIEGU COVID-19 - PRZEGLĄD PIŚMIENNICTWA}

\author{
${ }^{1}$ Medical University of Lublin, Students' Scientific Association of Chair and Department of Epidemiology \\ and Clinical Research Methodology \\ ${ }^{2}$ Medical University of Lublin, Chair and Department of Epidemiology and Clinical Research Methodology \\ ${ }^{1}$ Uniwersytet Medyczny w Lublinie, Studenckie Koło Naukowe przy Katedrze i Zakładzie Epidemiologii \\ i Metodologii Badań Klinicznych \\ ${ }^{2}$ Uniwersytet Medyczny w Lublinie, Katedra i Zakład Epidemiologii i Metodologii Badań Klinicznych
}

\section{ABSTRACT}

INTRODUCTION. The aim of the study is to present the current state of knowledge on the influence of vitamin D levels on the severity of the course of COVID-19.

MATERIAL AND METHODS. The latest available literature was reviewed until October 30, 2020 from the PubMed database.

RESULTS. The literature reports that vitamin D has immunomodulatory and anti-inflammatory effects. It reduces the expression of cytokines such as IL-6, TNF- $\alpha$ and INF- $\gamma$, regulates the activity of T helper lymphocytes, and other elements of the immune system at the molecular level. The deficiency of this vitamin promotes the activation of the renin-angiotensin-aldosterone system, contributing to the development of acute respiratory distress syndrome. The severity of the course of SARS-CoV-2 infection depends on comorbidities, the development and course of which may also be affected by vitamin D levels (coagulopathies, pulmonary, cardiological, metabolic diseases). Most of the analyzed research studies from different countries indicated a relationship between insufficient vitamin D levels and a more severe course of COVID-19 and an increase in mortality due to it, especially among the elderly. Researchers agree that further analyzes are necessary concerning both the influence of the vitamin D blood serum levels on the morbidity and mortality due to COVID-19 as well as the use of its supplementation in the struggle against SARS-CoV-2 virus. There are reports of possible beneficial interactions of vitamin D with other substances, such as quercetin, estradiol, some microelements, and other vitamins.

CONCLUSIONS. Maintaining an adequate level of vitamin D has a positive effect on the functioning of the immune system. At the moment, there is insufficient evidence to establish a clear relationship between vitamin D levels and the severity of COVID-19. It is necessary to conduct further research on a larger study group. The literature does not mention the use of vitamin D as a medication for COVID-19. People at risk of vitamin D deficiency should consider vitamin D supplementation at the current time of the pandemic.

Key words: vitamin D, COVID-19, SARS-CoV-2

\section{STRESZCZENIE}

CEL. Celem pracy jest przedstawienie aktualnego stanu wiedzy na temat wpływu poziomu witaminy D na stopień ciężkości przebiegu COVID-19.

MATERIAL I METODY. Dokonano przeglądu najnowszej dostępnej literatury do dnia 30.10.2020 z bazy danych PubMed. 
WYNIKI. Witamina D ma działanie immunomodulujące i przeciwzapalne. Zmniejsza ekspresję cytokin takich, jak IL-6, TNF- $\alpha$ i INF- $\gamma$, reguluje działanie limfocytów T pomocniczych oraz innych elementów układu odpornościowego na poziomie molekularnym. Niedobór tej witaminy sprzyja aktywacji układu renina-angiotensyna-aldosteron, przyczyniając się do rozwoju zespołu ostrej niewydolności oddechowej. Stopień ciężkości przebiegu zakażenia SARS-CoV-2 zależy od chorób współistniejących, na których rozwój i przebieg poziom witaminy D również może mieć wpływ (koagulopatie, schorzenia pulmonologiczne, kardiologiczne, metaboliczne). Większość analizowanych prac badawczych z różnych krajów wskazała na związek niewystarczającego poziomu witaminy D z cięższym przebiegiem COVID-19 i zwiększeniem śmiertelności z jej powodu, szczególnie wśród osób starszych. Badacze są zgodni co do konieczności prowadzenia dalszych analiz dotyczących zarówno wpływu poziomu witaminy D w surowicy krwi na zachorowalność i śmiertelność z powodu COVID-19, jak i wykorzystywania jej suplementacji w walce $\mathrm{z}$ wirusem SARS-CoV-2. Pojawiają się doniesienia o możliwych korzystnych interakcjach witaminy D z innymi znanymi substancjami, takimi jak kwercetyna, estradiol, niektóre mikroelementy i inne witaminy.

WNIOSKI. Utrzymywanie odpowiedniego poziomu witaminy D wpływa pozytywnie na funkcjonowanie układu odpornościowego. Nie ma na ten moment wystarczających dowodów na stwierdzenie jednoznacznego związku między poziomem witaminy D a ciężkością przebiegu COVID-19. Autorzy nie postulują za zastosowaniem witaminy D jako leku na chorobę COVID-19. Osoby z grupy ryzyka niedoboru witaminy D powinny rozważyć jej suplementację w obecnym czasie pandemii.

Słowa kluczowe: witamina D, COVID-19, SARS-CoV-2

\section{INTRODUCTION}

The outbreak of the new coronavirus SARS-CoV-2 pandemic has prompted scientists to search for an effective vaccine, drugs, and other substances that might potentially alleviate the course of infection, strengthen immunity and help fight the disease until an effective treatment regimen is determined. In the spring of 2020, reports began to appear in the scientific literature about the impact of vitamin D levels in the body on the severity of COVID-19 and hence the decrease of mortality due to this disease. Vitamin D is a substance with a high safety profile, widely used in clinical practice.

Vitamin $\mathrm{D}$ is a fat-soluble organic steroid chemical. The source of vitamin D for humans is both endogenous production by ultraviolet radiation and exogenous food consumption (1). In the liver, vitamin D converts to 25-hydroxyvitamin D - 25(OH)D, which is the major circulating metabolite of vitamin $\mathrm{D}$ and is used as an indicator of vitamin D status. The active form of vitamin $\mathrm{D}$ is 1,25-dihydroxyvitamin $\mathrm{D}$ $1,25(\mathrm{OH}) 2 \mathrm{D}$ called calcitriol (2). Vitamin D deficiency is a problem affecting over a billion people worldwide and may be associated with an increased incidence of infectious diseases of the respiratory system, such as influenza and community-acquired pneumonia $(1,3,4)$. The main reason for a severe course and deaths due to COVID-19 is acute respiratory distress syndrome (ARDS) as a consequence of an exacerbated inflammatory response with uncontrolled oxidative stress and inflammation at the lung level (3). It was shown that the cytokine storm is intensified with vitamin D deficiency (2).

\section{WSTĘP}

Wybuch pandemii nowego koronawirusa SARSCoV-2 skłonił naukowców do poszukiwań skutecznej szczepionki, leków oraz innych substancji, które potencjalnie mogą złagodzić przebieg infekcji, wzmocnić odporność i pomóc $\mathrm{w}$ walce $\mathrm{z}$ chorobą do czasu ustalenia skutecznego schematu leczenia. W literaturze naukowej zaczęły pojawiać się wiosną 2020 roku doniesienia o wpływie poziomu witaminy $\mathrm{D}$ w organizmie na stopień ciężkości przebiegu COVID-19, a co za tym idzie zmniejszenie śmiertelności z powodu tej choroby. Witamina D jest substancją o dużym profilu bezpieczeństwa, szeroko stosowaną w praktyce klinicznej.

Witamina D jest organicznym steroidowym związkiem chemicznym rozpuszczalnym w thuszczach. Źródłem witaminy D dla człowieka jest zarówno produkcja endogenna pod wpływem promieniowania ultrafioletowego, jak i spożycie egzogenne wraz z pokarmem (1). W wątrobie witamina $\mathrm{D}$ przekształca się w 25-hydroksywitaminę D - 25(OH)D, która jest głównym krążącym metabolitem witaminy $\mathrm{D}$, stosowanym jako wskaźnik statusu witaminy D. Aktywną formą witaminy D jest 1,25-dihydroksywitamina D $1,25(\mathrm{OH}) 2 \mathrm{D}$, czyli kalcytriol (2). Niedobór witaminy D jest problemem dotykającym ponad miliard ludzi na świecie i może być związany ze zwiększeniem zapadalności na choroby zakaźne układu oddechowego, takie jak grypa oraz pozaszpitalne zapalenie płuc $(1,3,4)$. Główną przyczyną ciężkiego przebiegu i zgonów z powodu COVID-19 jest zespół ostrej niewydolności oddechowej (ARDS) będący konsekwencją zaostrzonej odpowiedzi zapalnej $\mathrm{z}$ niekontrolowanym stresem 


\section{THE AIM OF THE STUDY}

The aim of the study is to present the current state of knowledge on the influence of vitamin D levels on the severity of COVID-19 disease.

\section{MATERIAL AND METHODS}

A review of the latest literature till 30 October 2020 has been made. The materials available in the PubMed database were used. Publications that met the following criteria were included: papers published from April 2020, in English and available as fulltext publications. Original and review papers were referred to, letters to the editor, as well as works with an annotation as "preprint" were not included. The literature review was conducted on 30 October 2020 using the following keywords: "vitamin D", "COVID-19", "SARS-CoV-2", "severity". 149 results were obtained, of which, after reading the abstracts, 26 papers were selected for analysis, meeting the adopted criteria.

\section{RESULTS}

\section{The mechanism of vitamin D's influence on the human immune system in the context of SARS- $\mathrm{CoV}-2$ infection}

It has been observed that vitamin D may have immunomodulatory and anti-inflammatory effects. Several in vitro studies have shown that by interacting with the vitamin D receptor (VDR) found on B and $\mathrm{T}$ lymphocytes, antigen-presenting cells, and lung epithelial cells, the calcitriol-VDR complex induces the transcriptional expression of antimicrobial peptides such as defensins and cathelicidin. Defensins promote inflammatory cell chemotaxis through increased capillary permeability, while cathelicidins destroy bacterial cell membranes as well as enveloped viruses such as SARS-CoV-2 $(1,3,5,6)$. Vitamin D has been shown to reduce the risk of respiratory tract infections through three main mechanisms: maintaining tight cell and gap connections, preventing infiltration of immune cells into the lungs and tissues of other respiratory organs, killing some viruses by stimulating antiviral mechanisms, and reducing the synthesis of pro-inflammatory cytokines by modulation of the immune system, which prevents the development of pneumonia $(1,2,3,5)$. Not only are immune cells target for active vitamin $\mathrm{D}$, but also the cells produce it and can activate this hormone locally, which confirms the autocrine or paracrine function of vitamin $\mathrm{D}$ in the immune system (2).

SARS-CoV-2 uses the host's angiotensinconverting enzyme (ACE) receptor to enter the alveolar oksydacyjnym oraz odczynem zapalnym na poziomie płuc (3). Wykazano, że przy niedoborze witaminy D nasilona jest burza cytokin (2).

\section{CEL PRACY}

Celem pracy jest przedstawienie aktualnego stanu wiedzy na temat wpływu poziomu witaminy D na stopień ciężkości przebiegu choroby COVID-19.

\section{MATERIAŁ I METODY}

Dokonano przeglądu najnowszej dostępnej literatury do dnia 30.10.2020 roku. Korzystano z materiałów dostępnych $\mathrm{w}$ bazie danych PubMed. Zastosowano następujące kryteria włączenia: prace opublikowane od kwietnia 2020 roku, w języku angielskim i dostępne jako publikacje pełnotekstowe. Odniesiono się do prac oryginalnych i przeglądowych, nie uwzględniono listów do redakcji, a także prac z adnotacją jako "preprint". Przeglądu literatury dokonano w dniu 30.10.2020 roku przy użyciu następujących słów kluczowych: "vitamin D", "COVID-19", "SARS-CoV-2", "severity". Uzyskano 149 wyników, spośród których po przeczytaniu abstraktów wybrano 26 prac do analizy spełniających przyjęte kryteria.

\section{WYNIKI}

\section{Mechanizm wpływu witaminy D na układ od- pornościowy czlowieka $w$ kontekście zakażenia SARS-CoV-2}

Zaobserwowano, że witamina D może działać immunomodulująco i przeciwzapalnie. W kilku badaniach in vitro wykazano, że w wyniku interakcji z receptorem witaminy D (VDR), który znajduje się na limfocytach B, T, komórkach prezentujących antygen i komórkach nabłonka płuc, kompleks kalcytriol-VDR indukuje transkrypcyjną ekspresję peptydów przeciwdrobnoustrojowych, takich jak defensyny i katelicydyny. Defensyny promują chemotaksję komórek zapalnych poprzez zwiększoną przepuszczalność naczyń włosowatych, podczas gdy katelicydyny niszczą błony komórkowe bakterii, a także wirusy otoczkowe, jakim jest SARS-CoV-2 $(1,3,5,6)$. Wskazuje się, że witamina $\mathrm{D}$ zmniejsza ryzyko infekcji dróg oddechowych poprzez trzy główne mechanizmy: utrzymanie szczelnych połączeń komórkowych i szczelinowych, co zapobiega infiltracji komórek odpornościowych w płucach i tkankach innych narządów układu oddechowego, niszczenie niektórych wirusów poprzez stymulację mechanizmów przeciwwirusowych oraz zmniejszenie syntezy cytokin prozapalnych poprzez modulację układu odpornościowego, co zapobiega rozwojowi zapalenia płuc $(1,2,3,5)$. Komórki odporno- 
and intestinal epithelial cells, and overactivation of the local renin-angiotensin-aldosterone system with an increase in angiotensin 2 can exacerbate inflammation in the form of cytokine storm, fibrosis, cell necrosis, and development of ARDS $(1,2,3,7)$. Angiotensin 2 has been shown to stimulate cell growth and proliferation of lung fibroblasts, as well as upregulating the expression of transforming growth factor- $\beta$ (TGF- $\beta$ ), which is involved in fibroblast differentiation into myofibroblasts, which increases the deposition of extracellular matrix proteins. Angiotensin is also involved in pneumonia by producing reactive oxygen species and releasing pro-inflammatory cytokines (2). Calcitriol has an anti-inflammatory effect in acute lung injury and ARDS by modulating the expression of ACE enzymes in the lungs (7). Vitamin D deficiency may have an impact on ARDS and heart failure, severe manifestations of COVID-19 disease, because the deficiency of this vitamin promotes the activation of the renin-angiotensin-aldosterone system, which may consequently lead to impaired pulmonary function and chronic cardiovascular disease $(1,3)$.

Maintaining vitamin D levels within normal limits reduces the effect of adverse immune sequelae preceding ARDS (cytokine storm) by reducing the expression of two key cytokines involved in its development: interleukin 6 (IL-6) and tumor necrosis factor $\alpha(\mathrm{TNF}-\alpha)(1,2,5,6)$. Vitamin D reduces the concentration of interferon $\gamma$ (INF- $\gamma$ ) involved in antiviral defense and increases the expression of anti-inflammatory cytokines by macrophages $(1,2,5)$. Taking into account the described molecular mechanism, it is suggested that patients with vitamin $\mathrm{D}$ deficiency are more likely to experience more severe symptoms of COVID-19 and/or worse disease prognosis (6). Vitamin D regulates both acquired and innate immunity $(6,7)$. It suppresses immune responses mediated by $\mathrm{T}$ helper cell type 1 (Th1), mainly by inhibiting the production of the pro-inflammatory cytokines IL-2 and IFN- $\gamma$. 1,25(OH)2D promotes the production of cytokines by the $\mathrm{T}$ helper cell type 2 (Th2), which helps to enhance indirect suppression of Th1 cells, complementing it with actions mediated by multiple cell types. Moreover, 1,25(OH)2D promotes the induction of regulatory $\mathrm{T}$ cells (Treg), thus inhibiting inflammatory processes $(1,5)$. The decrease in immunity of the elderly and the more severe course of COVID-19 in these people is associated, among others, with a reduced ability to produce endogenous vitamin $\mathrm{D}-1,25(\mathrm{OH}) 2 \mathrm{D}(3,5)$. Vitamin $\mathrm{D}$ has also been shown to stimulate the maturation of immune cells, and epidemiological studies suggest an inverse relationship between circulating $25(\mathrm{OH}) \mathrm{D} 3$ levels, a biomarker of vitamin D status, and biomarkers of inflammation, including acute-phase protein - C-reactive protein ściowe są nie tylko celem dla aktywnej witaminy D, ale również lokalnie ją produkują i są w stanie aktywować ten hormon w sposób miejscowy, co potwierdza autokrynną lub parakrynną funkcję witaminy D w układzie odpornościowym (2).

Wirus SARS-CoV-2 wykorzystuje receptor enzymu konwertującego angiotensynę 2 (ACE) u gospodarza w celu dostania się do komórek nabłonka pęcherzyków płucnych i jelit, a nadmierna aktywacja lokalnego układu renina-angiotensyna-aldosteron ze wzrostem ilości angiotensyny 2 może prowadzić do zaostrzenia stanu zapalnego w postaci burzy cytokinowej, włóknienia, martwicy komórek i rozwoju ARDS $(1,2,3,7)$. Wykazano, że angiotensyna 2 stymuluje wzrost komórek i proliferację fibroblastów płuc, jak również reguluje w górę ekspresję transformującego czynnika wzrostu- $\beta$ (TGF- $\beta$ ), który jest związany z różnicowaniem fibroblastów do miofibroblastów, co zwiększa odkładanie białek macierzy zewnątrzkomórkowej. Angiotensyna bierze ponadto udział w zapaleniu płuc poprzez wytwarzanie reaktywnych form tlenu i uwalnianie prozapalnych cytokin (2). Kalcytriol wykazuje działanie przeciwzapalne w ostrym uszkodzeniu płuc i ARDS poprzez modulowanie ekspresji enzymów ACE w płucach (7). Niedostateczna ilość witaminy D może mieć wpływ na ARDS i niewydolność serca, ciężkie manifestacje choroby COVID-19, ponieważ niedobór tej witaminy sprzyja aktywacji układu renina-angiotensyna-aldosteron, co może w konsekwencji prowadzić do upośledzenia czynności płuc oraz przewlekłej choroby sercowo-naczyniowej $(1,3)$.

Utrzymanie poziomu witaminy $\mathrm{D} w$ granicach normy zmniejsza efekt niekorzystnych następstw immunologicznych poprzedzających ARDS (burzy cytokin) poprzez zmniejszenie ekspresji dwóch kluczowych cytokin zaangażowanych w jej rozwój: interleukiny 6 (IL-6) oraz czynnika martwicy nowotworu $\alpha$ (TNF- $\alpha$ ) $(1,2,5,6)$. Witamina D zmniejsza stężenie interferonu $\gamma(\mathrm{INF}-\gamma)$ zaangażowanego $\mathrm{w}$ obronę przeciwwirusową oraz zwiększa ekspresję cytokin przeciwzapalnych przez makrofagi $(1,2,5)$. Biorąc pod uwagę opisany mechanizm molekularny, sugeruje się, że pacjenci z niedoborem witaminy $\mathrm{D}$ są bardziej narażeni na cięższe objawy COVID-19 i/lub gorsze rokowanie (6). Witamina $\mathrm{D}$ reguluje odporność zarówno nabytą, jak i wrodzoną $(6,7)$. Tłumi odpowiedzi immunologiczne, w których pośredniczą limfocyty $\mathrm{T}$ pomocnicze typu 1 (Th1), głównie poprzez hamowanie wytwarzania prozapalnych cytokin IL-2 i INF- $\gamma$. 1,25(OH)2D wspomaga produkcję cytokin przez komórki pomocnicze T typu 2 (Th2), co pomaga wzmocnić pośrednią supresję komórek Th1, uzupełniając ją działaniami, w których pośredniczy wiele typów komórek. Ponadto $1,25(\mathrm{OH}) 2 \mathrm{D}$ sprzyja indukcji limfocytów T regulatorowych (Treg), hamując tym samym procesy zapalne 
(CRP) (4). A characteristic consequence of COVID-19 is pulmonary fibrosis. It is therefore worth mentioning that vitamin $\mathrm{D}$ prevents a profibrotic phenotype of lung cells induced by TGF- $\beta 1$ (4). The summary is presented in the table below (Tab. I).

Table I. Summary of the influence of vitamin D on individual elements of the human immune system

Tabela I. Podsumowanie wpływu witaminy D na poszczególne elementy układu immunologicznego człowieka

\begin{tabular}{|c|l|}
\hline $\begin{array}{c}\text { The influence } \\
\text { of vitamin D }\end{array}$ & \multicolumn{1}{c|}{ Part of the immune system } \\
\hline \multirow{5}{*}{ suppression } & $\begin{array}{l}\text { production of IL-2, IL-6, IL-12, IL- } \\
\text { 17, IL-23, INF- } \gamma \text {, TNF- } \alpha \text {, NF-kB } \\
\text { transcription factor, maturation of } \\
\text { dendritic cells, presentation of antigens } \\
\text { to Th lymphocytes, Th1 and 17 } \\
\text { lymphocytes activity, expansion of B } \\
\text { lymphocytes, development of plasma } \\
\text { cells and secretion of IgG antibodies }\end{array}$ \\
\hline \multirow{3}{*}{ activation } & $\begin{array}{l}\text { production of IL-4, IL-5, IL-10, IL- } \\
\text { 37, defensin and cathelicidin, activity } \\
\text { of Th2 and Treg lymphocytes, } \\
\text { differentiation of macrophages }\end{array}$ \\
\hline
\end{tabular}

sources: own study based on the literature $[1,2,5,6,7,8,9]$

\section{Mechanism of vitamin D influence on the course of comorbidities in the context of SARS-CoV-2 infection}

Research agrees that people with coexisting diseases account for a higher proportion of severe COVID-19 cases $(1,2,3,9,10,11,12)$. This group mainly includes the elderly, who are characterized by an impaired immune response and usually suffer from many diseases, nutrient absorption dysfunctions, including lipids, vitamins $\mathrm{A}, \mathrm{D}, \mathrm{E}$, and $\mathrm{K}$, also deficiencies of nutrients and microelements $(4,10)$. Additionally, anticancer, antihypertensive drugs, or antibiotics use increases with age. These medications by activating the pregnane-X receptor, reduce the concentration of $25(\mathrm{OH}) \mathrm{D}(2,5)$. It has been noticed that the severity of the course of SARS-CoV-2 infection depends on coexisting diseases, the development and course of which may be also affected by vitamin D levels.

Vitamin D deficiency by disrupting the immune system contributes to increased susceptibility to infections such as tuberculosis, flu, HIV, EBV, HCV infections, or systemic fungal infections $(7,9,11,12,14)$. The beneficial effects of vitamin D supplementation have been confirmed in the treatment of hepatitis $\mathrm{C}$ virus (HCV), human immunodeficiency virus (HIV), and Dengue virus $(5,12,13)$. Vitamin D can reduce the risk of lung damage and ARDS by decreasing apoptosis and stimulating the synthesis of surfactant in pneumocytes (9). However, vitamin D insufficient
$(1,5)$. Spadek odporności osób starszych oraz cięższy przebieg COVID-19 u tych osób wiązany jest między innymi ze zmniejszoną zdolnością produkcji endogennej witaminy $\mathrm{D}-1,25(\mathrm{OH}) 2 \mathrm{D}(3,5)$. Wskazuje się, że witamina $\mathrm{D}$ stymuluje również dojrzewanie komórek odpornościowych, a badania epidemiologiczne sugerują odwrotną zależność między krążącym poziomem $25(\mathrm{OH}) \mathrm{D} 3$, biomarkerem statusu witaminy D a biomarkerami zapalenia, w tym białkiem C-reaktywnym (CRP) należącym do białek ostrej fazy (4). Charakterystycznym następstwem COVID-19 jest zwłóknienie płuc. Warto więc wspomnieć, że witamina D zapobiega indukowanemu przez TGF- $\beta 1$ fenotypowi profibrotycznemu komórek płuc (4). Podsumowanie zebrano w poniższej tabeli (Tab. I).

\section{Mechanizm wplywu witaminy D na przebieg chorób towarzyszących $w$ kontekście zakażenia SARS-CoV-2}

Badania są zgodne, że osoby z chorobami współistniejącymi stanowią wyższy odsetek ciężkich przypadków COVID-19 $(1,2,3,9,10,11,12)$. Do tej grupy najczęściej należą osoby starsze, które cechuje upośledzona zdolność odpowiedzi immunologicznej, obecność wielu przewlekłych schorzeń, zaburzeń wchłaniania substancji pokarmowych, m.in. tłuszczy, witamin A, D, E i K, a także niedoborów składników odżywczych i mikroelementów $(4,10)$. Dodatkowo, wraz z wiekiem stosowane są coraz częściej leki przeciwnowotworowe, hipotensyjne czy antybiotyki, które mogą zmniejszać stężenie $25(\mathrm{OH}) \mathrm{D}$ poprzez aktywację receptora pregnane-X $(2,5)$. Wykazano, że stopień ciężkości przebiegu zakażenia SARS-CoV-2 zależy od chorób współistniejących, na których rozwój i przebieg poziom witaminy $\mathrm{D}$ również może mieć wpływ.

Niedobór witaminy D poprzez zaburzenie funkcjonowania układu immunologicznego przyczynia się do zwiększania podatności na choroby zakaźne, takie jak gruźlica, grypa, infekcja wirusem HIV, EBV, HCV czy ogólnoustrojowe zakażenie grzybicze $(7,9,11,12,14)$. W zakażeniach wirusem zapalenia wątroby typu C (HCV), ludzkim wirusem niedoboru odporności (HIV) oraz wirusem Denga potwierdzono korzystne działanie terapii z wykorzystaniem witaminy D $(5,12,13)$. Zmniejszenie ryzyka uszkodzenia płuc i wystąpienia ARDS jest możliwe w wyniku zmniejszenia apoptozy i stymulacji syntezy surfaktantu w pneumocytach przez witaminę D (9). Jednak niedobór witaminy zwiększa ryzyko wystąpienia nie tylko zakażeń układu oddechowego, zaostrzenia zapalenia płuc, skutkującym ARDS, ale i astmy, nowotworów, zaburzeń poznawczych oraz schorzeń układu sercowo -naczyniowego $(4,5,10,13)$.

Podejrzewa się, iż witamina D może mieć działanie neuroprotekcyjne, wykorzystywane w hamowa- 
level increases the risk not only of respiratory infections, exacerbation of pneumonitis, resulting in ARDS, but also asthma, cancers, cognitive disorders, and cardiovascular diseases $(4,5,10,13)$.

It is suspected vitamin D may have a neuroprotective function, used in inhibiting the development of neurodegenerative diseases, including Parkinson's disease, but also preventing complications of SARSCoV-2 infection and depression, the risk of which increases because of isolation, a difficult financial situation due to economic crisis or the COVID-19 infection itself $(9,10)$. In the course of SARS-CoV-2 infection as a stress reaction, the liver and pancreas are exposed to injury, but the use of synthetic vitamin $\mathrm{D}$ analog - paricalcitol can have a protective effect. This drug, by activating VDR, found in stellate cells of the liver and pancreas, contributing to decreasing TGF- $\beta$ level, prevents the occurrence of inflammatory changes, fibrosis, and dysfunction of these organs (15). Moreover, paricalcitol slowed down the course of diabetic nephropathy in animal studies (2).

Lower vitamin D level, often reported in obese people, is considered a risk factor for hypertension, diabetes mellitus, and metabolic syndrome - diseases that worsen the course of SARS-CoV-2 infection $(4,11)$. At the same time, obesity can be a contraindication to the use of extracorporeal membrane oxygenation (ECMO) in the management of infection and worsen the patient's prognosis. Another important factor increasing morbidity and mortality is coagulopathy, related to, inter alia, with endothelial damage, while vitamin D may not only have antiviral and immunomodulating function, but also anticoagulant $(12,13)$. Anticoagulative effects may be a result of increasing the level of thrombomodulin, glutathione and reducing oxidative stress and the level of tissue thromboplastin - blood coagulation factor III (12).

Due to the beneficial effect on the immune system and inhibition of viral replication by vitamin $\mathrm{D}, \mathrm{A}$, E, C, zinc, and selenium and their pleiotropic effect, prophylactic supplementation of all these substances should be considered $(4,13)$.

\section{DISCUSSION OF RESEARCH RESULTS}

A number of 11 research papers were included in the review. In one of them, performed in the United Kingdom, it was decided to investigate the influence of 25(OH)D in the blood on the incidence of COVID-19 as well as to explain the greater incidence of this disease in ethnic minorities. The values of $25(\mathrm{OH}) \mathrm{D}$ concentrations were obtained for 348,598 people, of which 449 were positive for COVID-19. There was found a lower median of $25(\mathrm{OH}) \mathrm{D}$ concentration at the time of recruitment in niu rozwoju chorób neurodegeneracyjnych, w tym choroby Parkinsona, ale też zapobieganiu powikłaniom infekcji SARS-CoV-2 i depresji, której ryzyko występowania wzrasta $\mathrm{w}$ czasie pandemii przez izolację, trudną sytuację finansową z powodu kryzysu gospodarczego, czy samo zachorowanie na COVID-19 $(9,10)$. W przebiegu infekcji wirusem SARS-CoV-2 jako reakcji stresowej, wątroba i trzustka są narażone na uszkodzenie, ale ochronne działanie może potencjalnie przynieść zastosowanie syntetycznego analogu witaminy D - parykalcytolu, który poprzez aktywację VDR, obecnego w komórkach gwiaździstych wątroby i trzustki, a w efekcie spadek TGF- $\beta$, zapobiega występowaniu zmian zapalnych, włóknienia i dysfunkcji tych narządów (15). Ponadto parykalcytol w badaniach na zwierzętach spowalniał przebieg nefropatii cukrzycowej (2).

Niższy poziom witaminy D, odnotowywany często u osób otyłych, uważany jest za czynnik ryzyka nadciśnienia, cukrzycy i rozwoju metabolicznego - schorzeń pogarszających przebieg infekcji wirusem SARS-CoV-2 $(4,11)$. Jednocześnie otyłość może stanowić przeciwwskazanie do zastosowania pozaustrojowego natleniania membranowego krwi (ECMO) w terapii zakażenia i pogarszać rokowanie pacjenta. Innym istotnym czynnikiem zwiększającym zachorowalność i śmiertelność jest koagulopatia, związana m.in. z uszkodzeniem śródbłonka, podczas gdy witamina D może mieć nie tylko działanie przeciwwirusowe i immunomodulacyjne, ale też przeciwzakrzepowe $(12,13)$. Działanie antykoagulacyjne może być efektem zwiększenia poziomu trombomoduliny, glutationu oraz zmniejszenia stresu oksydacyjnego i poziomu tromboplastyny tkankowej - III czynnika krzepnięcia krwi (12).

Z powodu korzystnego działania na układ odpornościowy i hamowania replikacji wirusów przez witaminy D, A, E, C, cynk i selen oraz ich plejotropowego efektu, powinna być rozważona wspólna profilaktyczna suplementacja tych substancji $(4,13)$.

\section{OMÓWIENIE WYNIKÓW PRAC BADAWCZYCH}

Do przeglądu włączono 11 prac badawczych. W jednej z nich, wykonanej w Wielkiej Brytanii postanowiono zbadać wpływ poziomu $25(\mathrm{OH}) \mathrm{D}$ we krwi na zachorowalność na COVID-19 oraz wyjaśnić większą zachorowalność na tę chorobę w mniejszościach etnicznych. Uzyskano wartości stężeń 25(OH)D dla 348598 osób, z czego 449 miało pozytywny test na COVID-19. Stwierdzono niższą medianę stężenia 25(OH)D w momencie rekrutacji u osób, które później zachorowały na COVID-19 w stosunku do innych uczestników (16). Nie wykryto jednak powiązania 
people who later developed COVID-19 compared to other participants (16). However, no association was found between insufficient and sufficient 25(OH)D levels and the incidence of COVID-19, both in terms of one factor and multifactorial. The authors found a higher incidence of COVID-19 infection in people from ethnic minority groups. Although lower $25(\mathrm{OH})$ $\mathrm{D}$ levels were found in black and South Asian people after adjusting for potential confounding factors, no association was found between $25(\mathrm{OH}) \mathrm{D}$ levels and COVID-19 infection (16). Therefore, the measurement of $25(\mathrm{OH}) \mathrm{D}$ levels was not recommended to determine the risk of developing the disease and vitamin D supplementation to reduce the incidence of COVID-19 (16). Another study conducted in the UK on 4,510 people did not find an independent association between 25(OH)D status and COVID-19 disease, but it suggested a relationship between vitamin D levels and BMI and ethnicity, which were associated with an increase in the incidence of this disease (17).

Another study was carried out in Italian-Swiss cooperation, which included 27 positive and 80 negative PCR testers for SARS-CoV-2, in whom 25(OH)D levels were measured (18). The control cohort was 1,377 people with $25(\mathrm{OH}) \mathrm{D}$ measurements in the same period of 2019 before the outbreak of the pandemic. Significantly lower levels of $25(\mathrm{OH}) \mathrm{D}$ were detected in SARS-CoV-2 positive people compared to negative persons (18). However, people with a negative test result had symptoms of a respiratory tract infection, which induced the PCR test, and in these patients, the level of $25(\mathrm{OH}) \mathrm{D}$ was lower than in the control group tested in 2019. The authors found a stronger correlation between $25(\mathrm{OH}) \mathrm{D}$ levels and the risk of SARS-CoV-2 infection than other respiratory infections (18). The differences in $25(\mathrm{OH}) \mathrm{D}$ levels were most noticeable in people over the age of 70 , which shows that vitamin D supplementation in this age group could reduce the risk of a severe course of COVID-19 infection (18).

A study conducted in California aimed to identify factors involved in the regulation of ACE2 and FURIN genes and to show gene interactions that could potentially affect SARS-CoV-2 infection. The effect of vitamin D and the VDR gene on the blockade of the expression of the ACE2 gene and the FURIN protease has been examined among others (19). The study showed that a hypothetical drug combination consisting of vitamin $\mathrm{D}$, quercetin, and estradiol could affect the expression of 244 out of 332 (73\%) human genes encoding the SARS-CoV-2 virus target proteins (19). It has been observed that the combination of both vitamin $\mathrm{D}$ and quercetin, as well as the addition of estradiol to them, has a statistically significantly stronger effect on the expression of SARS-CoV-2 target genes compared to monotherapy with these substances między niedostatecznym i wystarczającym poziomem 25(OH)D a występowaniem COVID-19 zarówno pod względem jednego czynnika, jak i wieloczynnikowo. Autorzy stwierdzili częstsze występowanie zakażenia COVID-19 u osób z grup mniejszości etnicznych. Mimo tego, iż stwierdzono niższy poziom 25(OH) D u osób rasy czarnej i południowo-azjatyckiej po uwzględnieniu potencjalnych czynników zakłócających, nie znaleziono powiązania pomiędzy poziomem 25(OH)D a infekcją COVID-19 (16). W związku z czym nie zalecono pomiaru poziomu $25(\mathrm{OH}) \mathrm{D}$ do określenia ryzyka zachorowania oraz suplementacji witaminy D w celu zmniejszenia zachorowalności na COVID-19 (16). Inne badanie wykonane w tym kraju na 4510 osobach nie wykryło niezależnego powiązania pomiędzy statusem 25(OH)D a chorobą COVID-19, natomiast zasugerowało związek poziomu witaminy D z BMI i pochodzeniem etnicznym, które to były powiązane ze wzrostem zachorowalności na tę chorobę (17).

Kolejne badanie wykonano we współpracy włosko-szwajcarskiej, do którego włączono 27 osób dodatnich i $80 \mathrm{z}$ negatywnym wynikiem testu PCR na SARS-CoV-2, u których wykonano pomiary poziomu 25(OH)D (18). Kohortę kontrolną stanowiło 1377 osób z pomiarem 25(OH)D w tym samym okresie roku 2019 przed wybuchem pandemii. Wykryto znacząco niższy poziom $25(\mathrm{OH}) \mathrm{D}$ u osób SARS-CoV-2 pozytywnych w stosunku do osób negatywnych (18). Osoby z negatywnym wynikiem testu miały jednak objawy infekcji dróg oddechowych, co skłoniło do wykonania badania PCR, a u pacjentów tych poziom $25(\mathrm{OH}) \mathrm{D}$ był niższy niż u osób z grupy kontrolnej badanej w 2019 roku. Autorzy stwierdzili silniejsze powiązanie między poziomem $25(\mathrm{OH}) \mathrm{D}$ a ryzykiem infekcji SARSCoV-2 niż innymi infekcjami układu oddechowego (18). Różnice w poziomach 25(OH)D były najbardziej widoczne u osób powyżej 70. roku życia, co ukazuje, że suplementacja witaminy D w tej grupie wiekowej mogłaby zmniejszyć ryzyko poważnego przebiegu infekcji COVID-19 (18).

Badanie przeprowadzone $\mathrm{w}$ Kalifornii miało na celu identyfikację czynników zaangażowanych w regulację działania genów ACE2 i FURIN oraz ukazanie interakcji genowych mogących potencjalnie wpływać na infekcje wirusem SARS-CoV-2. Przebadano m.in. wpływ witaminy D i genu VDR na blokadę ekspresji genu ACE2 oraz proteazy FURIN (19). W badaniu ukazano, że hipotetyczna kombinacja leków składająca się z witaminy D, kwercetyny i estradiolu może wpływać na ekspresję 244 z 332 (73\%) ludzkich genów kodujących białka docelowe wirusa SARSCoV-2 (19). Zaobserwowano, że połączenie zarówno witaminy D z kwercetyną, jak i dodatek do nich estradiolu, ma istotnie statystycznie silniejszy wpływ na 
(19). The author of the study proposes to start clinical trials on the use of a combination of vitamin D with quercetin for the prevention of infection and vitamin $\mathrm{D}$, quercetin, and estradiol to alleviate the symptoms of COVID-19 infection.

In the United States, Kaufman H.W. et al. decided to assess the relationship between the level of 25(OH)D in the blood and a positive test for SARS-CoV-2 virus infection. Ultimately, 191,779 patients were included in the analysis (20). An inverse relationship was found between blood 25(OH)D levels and a positive SARS-CoV-2 test. This relationship was maintained regardless of latitude, race (however, it was more pronounced in black patients), ethnicity, sex, and age range (20). Considering the entire population, people with $25(\mathrm{OH}) \mathrm{D}<20 \mathrm{ng} / \mathrm{mL}(<50 \mathrm{nmol} / \mathrm{L})$ had a $54 \%$ higher test positive rate than those with $30-34 \mathrm{ng} / \mathrm{mL}$ $(75-85 \mathrm{nmol} / \mathrm{L})(20)$. For each increase in $25(\mathrm{OH}) \mathrm{D}$ by $\mathrm{ng} / \mathrm{mL}$, the risk of a positive SARS-CoV-2 test was reduced by $1.6 \%$ (20). Another study made at Chicago, which finally enrolled 489 people found that persons who were likely to be deficient in vitamin D while being tested for COVID-19 were significantly more likely to test positive than patients who were likely to have vitamin D levels in the norm (21). Patients were considered as vitamin $\mathrm{D}$ deficient if their last serum vitamin $\mathrm{D}$ level in the 1 year before the first COVID-19 test was less than $20 \mathrm{ng} / \mathrm{mL}(50 \mathrm{nmol} / \mathrm{L})$ for 25-hydroxycholecalciferol. Moreover, in people with vitamin D deficiency who had an increased dose of treatment, no increased risk of a positive COVID-19 test result was observed concerning people with normal vitamin D levels (21). This may suggest a protective effect of vitamin D supplementation against SARSCoV-2 infection, however, the confidence intervals for the estimated coefficients are too wide, which requires further research on this topic (21).

In an Austrian prospective study, Pizzini A. et al. decided to analyze the status of vitamin D in the body and its relationship with the clinical picture and the course of COVID-19. The study included 22 outpatients and 87 inpatients. Vitamin D deficiency was defined as $25(\mathrm{OH}) \mathrm{D}$ level $<12 \mathrm{ng} / \mathrm{mL}(<30 \mathrm{nmol} / \mathrm{L})$. Concentrations of $12-20 \mathrm{ng} / \mathrm{mL}(30-50 \mathrm{nmol} / \mathrm{L})$ were classified as insufficient supply, while $>40 \mathrm{ng} / \mathrm{mL}$ $(>100 \mathrm{nmol} / \mathrm{L}$ ) was considered as the norm (22). It was shown that vitamin $\mathrm{D}$ deficiency was common among people with COVID-19, however, low 25(OH) $\mathrm{D}$ levels are not predictive of disease severity and are not associated with observed symptoms, changes in $\mathrm{CT}$, or abnormalities in lung function tests (both in at the time of diagnosis of COVID-19 and after 8 weeks) (22). Patients with severe symptoms of the disease show disturbances in the parathyroid-vitamin D axis during the recovery phase (increase in PTH levels), ekspresję genów docelowych SARS-CoV-2 w porównaniu do monoterapii tymi substancjami (19). Autor badania proponuje rozpoczęcie badań klinicznych nad wykorzystaniem połączenia witaminy D z kwercetyną do profilaktyki zakażenia oraz witaminy $\mathrm{D}$, kwercetyny i estradiolu do łagodzenia objawów infekcji COVID-19.

W Stanach Zjednoczonych Kaufman H.W. i wsp. postanowił ocenić związek między poziomem $25(\mathrm{OH})$ D we krwi a pozytywnym wynikiem testu na infekcje wirusem SARS-CoV-2. Ostatecznie do analizy włączono 191779 pacjentów (20). Wykryto odwrotną zależność między poziomem $25(\mathrm{OH}) \mathrm{D}$ we krwi a pozytywnym wynikiem testu SARS-CoV-2. Zależność ta utrzymywała się niezależnie od szerokości geograficznej, rasy (jednak była bardziej widoczna u czarnoskórych pacjentów), pochodzenia etnicznego, płci i przedziału wiekowego (20). Biorąc pod uwagę całą populację, osoby z poziomem $25(\mathrm{OH}) \mathrm{D}<20 \mathrm{ng} / \mathrm{ml}(<$ $50 \mathrm{nmol} / 1)$ miały o $54 \%$ wyższy wskaźnik pozytywności testu w stosunku do osób z wartościami 30-34 $\mathrm{ng} / \mathrm{ml}(75-85 \mathrm{nmol} / \mathrm{l})(20)$. Na każdy wzrost poziomu $25(\mathrm{OH}) \mathrm{D}$ o $\mathrm{ng} / \mathrm{ml}$ ryzyko pozytywnego testu na SARS-CoV-2 zmniejszało się o 1,6\% (20). Inne badanie wykonane w Chicago, do którego ostatecznie włączono 489 osób podaje, że osoby, które miały prawdopodobnie niedobór witaminy $\mathrm{D}$ w trakcie wykonywania testu na COVID-19, były znacznie bardziej narażone na pozytywny wynik testu niż pacjenci, którzy prawdopodobnie mieli poziom tej witaminy w normie (21). Pacjentów uznano za osoby z niedoborem witaminy $\mathrm{D}$, jeśli ich ostatni poziom witaminy $\mathrm{D}$ w surowicy w ciągu 1 roku przed pierwszym testem COVID-19 wynosił mniej niż $20 \mathrm{ng} / \mathrm{ml}(50 \mathrm{nmol} / \mathrm{l})$ dla 25-hydroksycholekalcyferolu. Ponadto u osób z niedoborem witaminy $\mathrm{D}$, które miały zwiększoną dawkę leczenia, nie zaobserwowano zwiększonego ryzyka pozytywnego wyniku testu na COVID-19 w stosunku do osób z poziomem witaminy $\mathrm{D} w$ normie (21). Może to sugerować efekt ochronny suplementacji witaminą D przed infekcją SARS-CoV-2, jednak przedziały ufności dla szacowanych współczynników są zbyt szerokie, przez co konieczne są dalsze badania na ten temat (21).

W austriackim badaniu prospektywnym Pizzini $A$. i wsp. postanowili przeanalizować status witaminy D w organizmie i jego związek z obrazem klinicznym i przebiegiem COVID-19. Do badania włączono 22 pacjentów ambulatoryjnych i 87 hospitalizowanych. Niedobór witaminy D zdefiniowano jako poziom $25(\mathrm{OH}) \mathrm{D}$ $<12 \mathrm{ng} / \mathrm{ml}(<30 \mathrm{nmol} / \mathrm{l})$. Stężenia $12-20 \mathrm{ng} / \mathrm{ml}(30-50$ $\mathrm{nmol} / \mathrm{l}$ ) zostały sklasyfikowane jako niewystarczająca podaż, podczas gdy $>40 \mathrm{ng} / \mathrm{ml}(>100 \mathrm{nmol} / \mathrm{l})$ uznano za normę (22). Ukazano, że niedobór witaminy D jest powszechny wśród osób z COVID-19, jednak niski poziom 25(OH)D nie jest wskaźnikiem przewidującym 
most likely due to long-term hospitalization and quarantine (22).

In a pilot study by Arvinte $C$., conducted on 21 critically ill COVID-19 patients in the intensive care unit of the North American Community Hospital, serum levels of vitamin $C$ and vitamin $D$ were assessed as well as potential standard risk factors such as age, BMI, HbAlc and smoking. Serum vitamin $\mathrm{C}$ and vitamin $D$ levels were low in the majority of critically ill patients in ICU (intensive care unit) with COVID-19 (23). However, many of the patients in the assessing cohort were diabetic or insulin-resistant, which are the risk factors for low vitamin C and vitamin D levels and the development of COVID-19. Besides, a significant part of the cohort was overweight or obese, so these patients showed additional risk factors for lowering the level of vitamin $\mathrm{C}$ and vitamin $\mathrm{D}$ in the blood serum (23). As shown in a study by Arvinte $C$. et al., age appeared to be a predictor of COVID-19 mortality. Its increase by 10 years increased the risk of death by 2.7 times $(\mathrm{OR}=2.7,95 \% \mathrm{CI}=1.01-5.10, \mathrm{p}=0.0474)$. It was also noticed that older age and low vitamin $\mathrm{C}$ levels in the blood serum are correlative risk factors for mortality due to COVID-19 (23).

Another study investigated the evidence of a possible role of vitamin D deficiency in unregulated cytokine production and inflammation leading to complications in COVID-19 patients. Daneshkhah A. et al. used data on COVID-19 cases and deaths from Kaggle, except for data from England, which was provided by the UK government. The time-adjusted case mortality rate (T-CMR) was estimated as the ratio of patients who died on Day $\mathrm{N}$ to confirmed cases on Day N-8 (24). The adaptive average T-CMR (A-CMR) was calculated as a measure of COVID-19 related mortality. The possible association of A-CMR with the mean concentration of 25-hydroxyvitamin D $(25(\mathrm{OH}) \mathrm{D})$ in elderly people in countries with a similar screening strategy was investigated. The high level of C-reactive protein (CRP) in patients with severe COVID-19 (CRP $\geq 1 \mathrm{mg} / \mathrm{dL}$ ) was considered to be indicative of a cytokine storm. The study showed that people with vitamin D deficiency have 34\% (age $\geq 60$ years), $22 \%$ ( 20 years $\leq$ age $<40$ years), and $21 \%$ (40 years $\leq$ age $<60$ years) more frequent high hs- CRP (high-sensitivity CRP) than patients with normal vitamin D status. A vitamin D deficiency was considered to be $25(\mathrm{OH}) \mathrm{D}$ concentration $<20 \mathrm{ng} / \mathrm{mL}$ $(<50 \mathrm{nmol} / \mathrm{L})(24)$. As a result, it was indicated that the link between 25(OH)D and A-CMR in countries with a similar screening strategy is evidence of the possible role of vitamin D in reducing unregulated cytokine production and inflammation in patients with severe COVID-19 (24). ciężkość choroby i nie wiąże się z zaobserwowanymi objawami, zmianami w badaniu CT lub nieprawidłowościami w testach czynnościowych płuc (zarówno w momencie postawienia diagnozy COVID-19, jak i po 8 tygodniach) (22). Pacjenci z ciężkimi objawami choroby wykazują zaburzenia w osi przytarczyce - witamina D w fazie zdrowienia (wzrost poziomu PTH), najprawdopodobniej z powodu długotrwałej hospitalizacji oraz kwarantanny (22).

W badaniu pilotażowym przeprowadzonym przez Arvinte $C$. na oddziale intensywnej terapii w North American Community Hospital na grupie 21 krytycznie chorych pacjentów z COVID-19, oceniano poziom witaminy $\mathrm{C}$ i witaminy $\mathrm{D}$ w surowicy pacjentów, jak również potencjalne, standardowe czynniki ryzyka, takie jak wiek, BMI, HbAlc i palenie tytoniu. Poziomy witaminy C i witaminy D w surowicy były niskie u większości krytycznie chorych pacjentów na OIOM-ie z COVID-19 (23). Jednakże, wielu pacjentów w ocenianej kohorcie było cukrzykami lub opornymi na insulinę, co stanowi czynnik ryzyka niskiego poziomu witaminy $\mathrm{C}$ i witaminy $\mathrm{D}$ oraz rozwoju COVID-19. Ponadto znaczna część osób należących do kohorty miała nadwagę lub otyłość, czyli wykazywała dodatkowe czynniki ryzyka obniżenia poziomu witaminy C i witaminy D w surowicy krwi (23). Jak dowiodły badania przeprowadzone przez Arvinte $C$. i wsp., wiek wydawał się być predyktorem śmiertelności z powodu COVID-19. Jego wzrost o 10 lat zwiększał ryzyko zgonu 2,7-krotnie $(\mathrm{OR}=2,7,95 \% \mathrm{CI}=$ $1,01-5,10, \mathrm{p}=0,0474)$. Dostrzeżono również, że starszy wiek i niski poziom witaminy $\mathrm{C}$ w surowicy krwi są współzależnymi czynnikami ryzyka śmiertelności z powodu COVID-19 (23).

W innym badaniu poszukiwano dowodów na możliwą rolę niedoboru witaminy $\mathrm{D}$ w nieuregulowanej produkcji cytokin i zapaleniu prowadzącym do powikłań u pacjentów z COVID-19. Daneshkhah A. i wsp. wykorzystali dane o przypadkach zakażenia COVID-19 i zgonach pochodzących od Kaggle, z wyjątkiem danych z Anglii, które zostały dostarczone przez rząd Wielkiej Brytanii. Współczynnik śmiertelności skorygowany względem czasu (T-CMR) oszacowano jako stosunek zmarłych pacjentów $\mathrm{W}$ dniu $\mathrm{N}$ do potwierdzonych przypadków w dniu N-8 (24). Adaptacyjną średnią T-CMR (A-CMR) obliczono jako miernik śmiertelności związanej z COVID-19. Zbadano możliwy związek A-CMR ze średnim stężeniem 25-hydroksywitaminy D $(25(\mathrm{OH}) \mathrm{D})$ u osób starszych w krajach o podobnej strategii badań przesiewowych. Uznano, że wysoki poziom białka C-reaktywnego (CRP) u pacjentów z ciężkim przebiegiem COVID-19 (CRP $\geq 1 \mathrm{mg} / \mathrm{dl}$ ) jest wykładnikiem burzy cytokinowej. Przeprowadzone badanie wskazało, że osoby z niedoborem witaminy D mają odpowiednio o $34 \%$ 
In the study by Singh S. et al., the main aim was to reevaluate the effect of vitamin D levels on the incidence and severity of COVID-19 in the European population. European countries with comparable UV exposure and dietary intakes of vitamin $\mathrm{D}$ were selected for analysis to reduce the impact of confounding variables. Data on the number of COVID-19 cases per million inhabitants and the number of deaths per million inhabitants were obtained on 8 April and 12 May 2020, from the world data portal Worldometers (25). Comparative analysis of data from the above-mentioned periods (8 April vs. 12 May) showed a significant increase in the negative correlation of vitamin D level with the number of COVID-19 cases per million people in the second period ( $\mathrm{r}(20)$ : $-0.5504 ; \mathrm{R} 2=0$, 3029; p-value: 0.0119 vs $\mathrm{r}(20)$ : -0.4435 ; R2 $=0.1967$; p-value: 0.0501) (25). However, due to the discrepancy of vitamin D levels from the average in separate subgroups, the need for dedicated exploratory studies with carefully selected target groups was indicated.

Another study was conducted in China to analyze the correlation between the average percentage of positive results for 5 human coronaviruses (SARSCoV-2, CoVHKU1, CoVNL63, CoVOC43, and CoV229E) in the United States and the corresponding dose of solar UV radiation using Spearman's and Kendall's rank correlation (26). The results showed that the average monthly percentage of positive results for four common coronaviruses, including SARS$\mathrm{CoV}-2$, was significantly negatively correlated with the dose of UV radiation from sunlight. Moreover, solar UV radiation showed a negative correlation with the early transmission of SARS-CoV-2, limiting its infectivity (26).

\section{VITAMIN D SUPPLEMENTATION}

Different criteria for the correct concentration of vitamin $\mathrm{D}$ in the blood make it difficult to interpret the results of individual studies conducted in different countries because the standards at the global level are not strictly established. For this reason, there is a different concentration range recognized as deficiency and differences in the percentage of people classified as vitamin $\mathrm{D}$ deficient. It is reported that the normal level of vitamin $\mathrm{D}$ in human blood should be $30-50 \mathrm{ng} /$ $\mathrm{mL}(75-125 \mathrm{nmol} / \mathrm{L})(1,9)$. It has been shown that 38 $\mathrm{ng} / \mathrm{mL}(95 \mathrm{nmol} / \mathrm{L})$ are already appropriate values to reduce the risk of acute viral respiratory infections (3).

In the case of low plasma vitamin D levels $<20 \mathrm{ng} /$ $\mathrm{mL}(<50 \mathrm{nmol} / \mathrm{L})$, supplementation $(40 \mu \mathrm{g} /$ day $)$ may act as a method of preventing the aggressive course of inflammation caused by the new coronavirus. For longterm prophylactic vitamin D intake, a dose of $\leq 100$ $\mu \mathrm{g} /$ day is recommended to avoid hypercalciuria with (wiek $\geq 60$ lat), $22 \%$ (20 lat $\leq$ wiek < 40 lat) i 21\% (40 lat $\leq$ wiek $<60$ lat) częstsze występowanie wysokiego hs-CRP (ang. high-sensitivity CRP) niż pacjenci z prawidłowym stanem witaminy $\mathrm{D}$. Za niedobór witaminy D przyjmowano stężenie $25(\mathrm{OH}) \mathrm{D}<20 \mathrm{ng} / \mathrm{ml}(<50$ nmol/l) (24). Jako rezultat wskazano, że powiązanie między 25(OH)D i A-CMR w krajach o podobnej strategii badań przesiewowych jest dowodem na możliwą rolę witaminy $\mathrm{D}$ w zmniejszaniu nieuregulowanej produkcji cytokin i stanu zapalnego u pacjentów z ciężkim COVID-19 (24).

W badaniu Singh $S$. i wsp. głównym celem była ponowna - druga ocena wpływu poziomu witaminy D na częstość występowania i ciężkość przebiegu COVID-19 wśród populacji europejskiej. Do analizy wybrano kraje Europy o porównywalnej ekspozycji na promieniowanie UV i podobnym spożyciu witaminy $\mathrm{D}$ wraz z dietą, aby zmniejszyć wpływ zmiennych zakłócających. Dane dotyczące liczby przypadków COVID-19 na milion mieszkańców i liczby zgonów na milion mieszkańców uzyskano z dnia 8 kwietnia i 12 maja 2020 r., ze światowego portalu danych Worldometers (25). Analiza porównawcza danych $\mathrm{z}$ wymienionych etapów (8 kwietnia vs. 12 maja) wskazała na istotny wzrost ujemnej korelacji poziomu witaminy D z liczbą przypadków COVID-19 na milion osób w późniejszym etapie ( $\mathrm{r}(20)$ : $-0,5504 ; \mathrm{R} 2=0,3029$; wartość p: 0,0119 vs r (20): -0,4435; R2 =0,1967; wartość p: 0,0501) (25). Jednak ze względu na rozbieżności poziomów witaminy D od średniej w wydzielonych podgrupach, wskazano na konieczność dedykowanych badań eksploracyjnych ze starannie dobranymi grupami docelowymi.

Kolejne badanie było przeprowadzone w Chinach i miało na celu analizę korelacji między średnim procentem pozytywnych wyników 5 ludzkich koronawirusów (SARS-CoV-2, CoVHKU1, CoVNL63, CoVOC43 i CoV229E) w Stanach Zjednoczonych a odpowiadającą mu dawką promieniowania słonecznego UV z wykorzystaniem testów korelacji rang Spearmana i Kendalla (26) Wyniki wykazały, że średni miesięczny odsetek pozytywnych wyników czterech powszechnych koronawirusów, w tym również SAR$\mathrm{S}-\mathrm{CoV}-2$, był istotnie ujemnie skorelowany z dawką promieniowania UV w świetle słonecznym. Ponadto promieniowanie słoneczne UV wykazywało negatywną korelację w odniesieniu do wczesnej transmisji SARS-CoV-2, ograniczając jego zakaźność (26).

\section{SUPLEMENTACJA WITAMINY D}

Różne kryteria prawidłowego stężenia witaminy D we krwi powodują trudności w interpretacji wyników poszczególnych badań przeprowadzonych w różnych krajach, ponieważ normy na poziomie globalnym nie 
the risk of kidney stones, as well as hypercalcemia. It was noted that supplementation at the early stage of infection was important for strengthening resistance to infection with RNA viruses such as SARS-CoV-2, but it did not bring results at the advanced stage of the disease (4).

To reduce the risk of infection, scientists recommend that those at risk of COVID-19 consider taking 10,000 IU/day $(250 \mu \mathrm{g})$ of vitamin D for several weeks to quickly raise $25(\mathrm{OH}) \mathrm{D}$ levels, followed by $5,000 \mathrm{IU} /$ day. The purpose should be to raise the $25(\mathrm{OH}) \mathrm{D}$ concentration above $40-60 \mathrm{ng} / \mathrm{mL}(100-150$ $\mathrm{nmol} / \mathrm{L})(2,5)$.

In countries where it is not possible to test the level of $25(\mathrm{OH}) \mathrm{D}$ commonly and it is known that vitamin $\mathrm{D}$ deficiency is frequent in the population, supplementation with 1000-2000 IU/day is indicated (7).

\section{CONCLUSIONS}

The available data allow us to conclude that maintaining an adequate level of vitamin D has a positive effect on the functioning of the immune system, which is particularly important during a pandemic. There was no unequivocal relationship between vitamin $\mathrm{D}$ levels and the severity of the course and mortality from COVID-19. Instead, studies have shown that severe vitamin D deficiency is often seen in critically ill patients and appears to be associated with a poor prognosis. To draw conclusions, it is necessary to conduct further observations on a larger study group. The authors of the analyzed studies do not provide evidence for the use of vitamin $\mathrm{D}$ as a drug for COVID-19 disease. People at risk of vitamin D deficiency should consider vitamin D supplementation during a pandemic, especially since the current lifestyle change associated with staying at home more often and less exposure to sunlight may further aggravate vitamin D deficiency. It also seems important to test combinations of vitamin $\mathrm{D}$ with other substances to increase the presumed effectiveness in the fight against SARS-CoV-2 virus infection.

\section{REFERENCES}

1. Ali N. Role of vitamin D in preventing of COVID-19 infection, progression and severity. J Infect Public Health 2020 Oct;13(10):1373-1380.

2. Malek Mahdavi A. A brief review of interplay between vitamin $\mathrm{D}$ and angiotensin-converting enzyme 2: implications for a potential treatment for COVID-19. Rev Med Virol 2020 Sep;30(5):e2119.

3. Martín Giménez VM, Inserra F, Tajer CD, et al. Lungs as target of COVID-19 infection: protective są ściśle ustalone. $Z$ tego powodu można spotkać się $\mathrm{z}$ innym zakresem stężenia uznanym jako niedobór i różnicami w odsetku osób klasyfikowanych jako osoby z deficytem witaminy D. Podaje się, że prawidłowy poziom witaminy $\mathrm{D}$ we krwi człowieka powinien wynosić 30-50 ng/ml (75-125 nmol/1) (1,9). Wykazano, że $38 \mathrm{ng} / \mathrm{ml}(95 \mathrm{nmol} / \mathrm{l})$ to już odpowiednie wartości, aby zmniejszyć ryzyko ostrych wirusowych infekcji dróg oddechowych (3).

W przypadku niskiego poziomu witaminy $\mathrm{D}$ w osoczu $<20 \mathrm{ng} / \mathrm{ml}(<50 \mathrm{nmol} / \mathrm{l})$, suplementacja (40 $\mu \mathrm{g} /$ dobę) może działać jako metoda zapobiegania agresywnemu przebiegowi zapalenia wywołanego przez nowego koronawirusa. Przy długoterminowym, profilaktycznym przyjmowaniu witaminy D zaleca się dawkę na poziomie $\leq 100 \mu \mathrm{g} / \mathrm{dobę,} \mathrm{aby} \mathrm{uniknąć} \mathrm{hiper-}$ kalciurii z ryzykiem wystąpienia kamieni nerkowych, a także hiperkalcemii. Zwrócono uwagę, że suplementacja na wczesnym etapie infekcji była ważna dla wzmocnienia odporności na infekcje wirusami RNA, jakim jest SARS-CoV-2, natomiast nie przynosiła rezultatów na zaawansowanym etapie choroby (4).

$\mathrm{W}$ celu zmniejszenia ryzyka infekcji, naukowcy zalecają, aby osoby zagrożone COVID-19 rozważyły przyjmowanie $10000 \mathrm{IU} /$ dobę $(250 \mu \mathrm{g})$ witaminy D przez kilka tygodni w celu szybkiego podniesienia stężenia $25(\mathrm{OH}) \mathrm{D}$, a następnie $5000 \mathrm{IU} /$ dobę. Celem powinno być podniesienie stężenia $25(\mathrm{OH}) \mathrm{D}$ powyżej $40-60 \mathrm{ng} / \mathrm{ml}(100-150 \mathrm{nmol} / \mathrm{l})(2,5)$.

W krajach, w których nie ma możliwości powszechnego badania poziomu 25(OH)D i wiadomo, że niedobór witaminy $\mathrm{D}$ jest częsty w populacji, wskazana jest suplementacja 1000-2000 IU/dobę (7).

\section{WNIOSKI}

Dostępne dane pozwalają wysnuć wniosek, że utrzymywanie odpowiedniego poziomu witaminy $\mathrm{D}$ wpływa pozytywnie na funkcjonowanie układu odpornościowego, co jest szczególnie istotne w czasie pandemii. Nie stwierdzono jednoznacznego związku między poziomem witaminy $\mathrm{D}$ a ciężkością przebiegu i śmiertelnością z powodu COVID-19. Badania wykazały natomiast, że ciężki niedobór witaminy $\mathrm{D}$ jest często obserwowany u pacjentów w stanie krytycznym i wydaje się być związany ze złym rokowaniem. Do wyciągnięcia ostatecznych wniosków konieczne jest prowadzenie dalszych obserwacji na większej grupie badanej. Autorzy analizowanych badań nie podają dowodów za zastosowaniem witaminy D jako leku na chorobę COVID-19. Osoby z grupy ryzyka niedoboru witaminy D powinny rozważyć jej suplementację w czasie pandemii, szczególnie że obecna zmiana trybu życia związana z częstszym przebywaniem w domach oraz mniejszą ekspozycją na światło słoneczne 
common molecular mechanisms of vitamin D and melatonin as a new potential synergistic treatment. Life Sci 2020 Aug 1;254:117808.

4. Alexander J, Tinkov A, Strand TA, et al. Early nutritional interventions with zinc, selenium and vitamin $\mathrm{D}$ for raising anti-viral resistance against progressive COVID-19. Nutrients 2020 Aug 7 ;12(8):2358.

5. Grant WB, Lahore H, McDonnell SL, et al. Evidence that vitamin D supplementation could reduce risk of influenza and COVID-19 infections and deaths. Nutrients 2020 Apr 2;12(4):988.

6. Munshi R, Hussein MH, Toraih EA, et al. Vitamin $\mathrm{D}$ insufficiency as a potential culprit in critical COVID-19 patients. J Med Virol 2020 Jul 27.

7. Chandran M, Chan Maung A, Mithal A, et al. Vitamin D in COVID-19: dousing the fire or averting the storm? - A perspective from the AsiaPacific. Osteoporos Sarcopenia 2020 Sep;6(3):97105.

8. Fiorino S, Gallo C, Zippi M, et al. Cytokine storm in aged people with CoV-2: possible role of vitamins as therapy or preventive strategy. Aging Clin Exp Res 2020 Oct;32(10):2115-2131.

9. $\mathrm{Xu} \mathrm{Y,} \mathrm{Baylink} \mathrm{DJ,} \mathrm{Chen} \mathrm{CS,} \mathrm{et} \mathrm{al.} \mathrm{The}$ importance of vitamin $d$ metabolism as a potential prophylactic, immunoregulatory and neuroprotective treatment for COVID-19. J Transl Med 2020 Aug 26;18(1):322.

10. Hribar CA, Cobbold PH, Church FC. Potential role of vitamin D in the elderly to resist COVID-19 and to slow progression of Parkinson's disease. Brain Sci 2020 May 8;10(5):284.

11. Teymoori-Rad M, Marashi SM. Vitamin D and Covid-19: from potential therapeutic effects to unanswered questions. Rev Med Virol 2020 Aug 28:e2159.

12. Vyas N, Kurian SJ, Bagchi D, et al. Vitamin D in prevention and treatment of COVID-19: current perspective and future prospects. J Am Coll Nutr 2020 Sep 1:1-14.

13. Liu G, Hong T, Yang J. A single large dose of vitamin $D$ could be used as a means of coronavirus disease 2019 prevention and treatment. Drug Des Devel Ther 2020 Aug 21;14:3429-3434.

14. Isaia G, Medico E. Associations between hypovitaminosis D and COVID-19: a narrative review. Aging Clin Exp Res 2020 Sep;32(9):18791881.

15. Evans RM, Lippman SM. Shining light on the COVID-19 pandemic: a vitamin D receptor checkpoint in defense of unregulated wound healing. Cell Metab 2020 Sep 11:S15504131(20)30485-X.

16. Hastie CE, Mackay DF, Ho F, et al. Vitamin $\mathrm{D}$ concentrations and COVID-19 infection in może dodatkowo pogłębiać jej niedobór. Istotne wydaje się być również przebadanie połączeń witaminy D $\mathrm{z}$ innymi substancjami $\mathrm{w}$ celu podwyższenia domniemanej skuteczności $\mathrm{w}$ walce $\mathrm{z}$ zakażeniem wirusem SARS-CoV-2.

UK Biobank. Diabetes Metab Syndr 2020 JulAug;14(4):561-565.

17. Raisi-Estabragh Z, McCracken $\mathrm{C}$, Bethell MS, et al. Greater risk of severe COVID-19 in Black, Asian and Minority Ethnic populations is not explained by cardiometabolic, socioeconomic or behavioural factors, or by $25(\mathrm{OH})$-vitamin D status: study of 1326 cases from the UK Biobank. J Public Health (Oxf) 2020 Aug 18;42(3):451-460.

18. D'Avolio A, Avataneo V, Manca A, et al. 25-hydroxyvitamin D concentrations are lower in patients with positive PCR for SARS-CoV-2. Nutrients 2020 May 9;12(5):1359.

19. Glinsky GV. Tripartite combination of candidate pandemic mitigation agents: vitamin $\mathrm{D}$, quercetin, and estradiol manifest properties of medicinal agents for targeted mitigation of the COVID-19 pandemic defined by genomicsguided tracing of SARS-CoV-2 targets in human cells. Biomedicines 2020 May 21;8(5):129.

20. Kaufman HW, Niles JK, Kroll MH, et al. SARS$\mathrm{CoV}-2$ positivity rates associated with circulating 25-hydroxyvitamin D levels. PLoS One 2020 Sep 17;15(9):e0239252.

21. MeltzerDO, Best TJ, Zhang H, et al. Association of vitamin D status and other clinical characteristics with COVID-19 test results. JAMA Netw Open 2020 Sep 1;3(9):e2019722.

22. Pizzini A, Aichner M, Sahanic S, et al. Impact of vitamin D deficiency on COVID-19 a prospective analysis from the CovILD registry. Nutrients 2020 Sep 11;12(9):2775.

23. Arvinte C, Singh M, Marik PE. Serum levels of vitamin $\mathrm{C}$ and vitamin $\mathrm{D}$ in a cohort of critically ill COVID-19 patients of a North American Community Hospital Intensive Care Unit in May 2020: a pilot study. Med Drug Discov 2020 Dec;8:100064.

24. Daneshkhah A, Agrawal V, Eshein A, et al. Evidence for possible association of vitamin D status with cytokine storm and unregulated inflammation in COVID-19 patients. Aging Clin Exp Res 2020 Oct;32(10):2141-2158.

25. Singh S, Kaur R, Singh RK. Revisiting the role of vitamin D levels in the prevention of COVID-19 infection and mortality in European countries post infections peak. Aging Clin Exp Res 2020 Aug;32(8):1609-1612.

26. Tang L, Liu M, Ren B, et al. Sunlight ultraviolet radiation dose is negatively correlated with the 
percent positive of SARS-CoV-2 and four other common human coronaviruses in the U.S. Sci Total Environ 2020 Aug 19;751:141816.

Received: 1.12 .2020

Accepted for publication: 30.12 .2020

Otrzymano: 1.12.2020 r.

Zaakceptowano do publikacji: $30.12 .2020 \mathrm{r}$.

\section{Address for correspondence:}

Adres do korespondencji:

Gabriela Ręka

Chair and Department of Epidemiology and Clinical Research Methodology

Medical University of Lublin

Radziwiłłowska 11, 20-080 Lublin, Poland

tel. 814486370

e-mail: gabrysia.reka@gmail.com 